\title{
Chapter 17 \\ Models of Change: Strategies to Make the Socio-ecological Transformation a Success
}

\author{
Kora Kristof
}

\begin{abstract}
Climate change and many other problems show us more and more clearly that fundamental change is necessary. However, many good ideas get stuck in implementation. Therefore, the question is how we can change more successfully. We take sports courses or go to music lessons to learn, to get better quickly or to avoid hurting ourselves. Professionals in sport, art and other fields also receive intensive coaching from experts. However, when it comes to making successful progress towards sustainability, people often rely on 'home recipes'. It is time to become more professional in this area as well. To achieve this, it is important to make targeted use of the findings of transformation research and key success factors as well as to develop transformation literacy. In this chapter, the models of change approach is presented, which focuses on central success factors for social change and shows ways to successful change.
\end{abstract}

Keywords Change process $\cdot$ Successful change $\cdot$ Models of change $\cdot$ Theories of change $\cdot$ Transformation $\cdot$ Transition $\cdot$ Success factors

\subsection{Introduction: Challenges}

How does transformation towards sustainability succeed? We all need an answer to this 'one million dollar'-question.

Since the 1980s, we have known that climate protection is necessary. The social debate on this issue has gained significant momentum in recent years with the Paris Agreement on Climate Protection and civil society protests such as Fridays for Future. Politicians but also more and more companies and citizens are setting out on the path to a fundamental transformation towards greenhouse gas neutrality. Their goal is to stop producing greenhouse gas emissions and if this is not $100 \%$ successful, to completely offset their remaining emissions.

K. Kristof $(\bowtie)$

Umweltbundesamt, Wörlitzer Pl. 1, 06844 Dessau, Germany

e-mail: kora.kristof@uba.de 
But it is not only climate change that requires change. The ecological limits of the earth are also evident, for example, in the loss of biodiversity, acidification, eutrophication and the unsustainable use of natural resources. Environmental problems also threaten human health - such as pollutants in air, water and food or noise.

Social issues, including global and intergenerational justice, also call for profound change.

Briefly summarised: Wherever we look, we see large and complex needs for change.

Resource-efficient, emission-neutral, equitable - these are central goals of the upcoming major changes if we take the stress limits of the earth system, the wellbeing of all people and the idea of global and intergenerational justice seriously (e. g. Rockström et al., 2009; Jackson, 2009; WBGU, 2011; Daschkeit et al., 2013).

For the necessary 'Energiewende', mobility transformation, food transformation and many other transformations, there are countless proposals for policy instruments (e. g. taxes) and measures (e. g. reparability of products) for the different target groups. These approaches are intensively discussed in sustainability-oriented science, the scientific policy advice based on them, as well as in the social debates and political processes. And they are constantly evolving. At the centre of this, transformative research is always the question of what should change concretely and in what direction.

Some ideas have been successfully implemented, in many other places, things are moving slowly or not at all, as one would wish and as would be necessary because of the urgent problems. We know a lot about what should change, but often fail miserably in the concrete implementation.

So, it is not enough for us to only deal with the question 'what should change'? Rather, it is becoming increasingly important to know how we can also successfully implement the upcoming changes. It is, therefore, a question of the central success factors for social change and their application in practice.

In addition, resistance and obstacles often characterise the everyday life of change. In order to deal with them, implicit models are often used that have formed more or less consciously in our heads from past experiences with change processes.

How the upcoming changes can be realised more successfully has also become increasingly interesting for science: Transformation research focuses on the central success factors for social change and their practical application. In addition to ex-post studies of change processes, ex-ante approaches are increasingly coming into focus, which identify the central success factors and allow the change agents to reflect on the change process and their role in it and to consistently use the central success factors (e. g. Rotmans \& Loorbach, 2009; Kristof 2010a, b; Smart CSO 2011; Geels, 2011; Rasmussen, 2013; Fünfschilling, 2014; Grießhammer et al., 2015; Smart CSO, 2015; Kristof, 2020). In addition to overall models, there are a number of approaches that focus on interesting partial aspects or that compare different approaches (e. g. Alexander et al., 2011; WBGU, 2011; Ernst and Welzer 2015; Heinecke et al., 2013; Loske, 2012; Rückert-John et al., 2014; Schneidewind and Singer-Brodowski 2013; Sommer and Welzer 2014; Welzer and Sommer et al., 2014; Wolff et al., 2018; 
Schneidewind, 2018; Schäpke 2018; Wagner and Grunwald 2019; Oberlack, 2019; Köhler 2019).

In a complex and dynamic world, there are neither 'recipes' nor guarantees for successful change processes. What we can use, however, are typical patterns and key success factors to increase the probability of success of our change processes. My 'models of change' approach, which has now been further developed, combines my own research findings, the insights from many in-depth interviews with experts of transformation research and from the more recent literature (see above), as well as experiential knowledge from my research-based policy consulting.

\subsection{How Can the Necessary Changes Succeed?}

Briefly summarised: Moreover, having good ideas for change is not enough. They do not automatically become accepted or realised. We need answers to the central question: How can the necessary changes succeed? What is needed is, firstly, knowledge of the success factors and patterns of success and secondly, their consistent use.

What are the most important success factors? The models of change approach provides a number of answers to this question (Kristof, 2020; Kristof 2011a; Kristof 2011b). Three illustrations give a brief overview of the models of change approach (see Figs. 17.1, 17.2 and 17.3).

\subsubsection{Core Skills}

I would like to start with the central skills, which are important success factors.

Figure 17.1 shows which competencies are central to the success of social change: The basic skills aim at the basic attitude towards change and resistances that arise in the process. Procedural competences ensure a successful handling of actors, time and complexity.

Let us take a brief look at the most frequently unused skills.

First of all, this is the reflexive and self-reflexive attitude of the change actors which is necessary for successful change processes. It is important to constantly reflect on the change and the change process with the necessary distance in order to be able to continuously adapt along the central success factors.

The challenge of 'loving resistance' is also difficult for many change agents. It is promising to deal actively and positively with resistances and conflicts of interest instead of seeing them as annoyance.

What someone perceives as resistance is a question of perspective: Is the behaviour of the change actors themselves not also resistant?

It is important not to see the representatives of resistance automatically as 'evil opponents', but to accept their legitimate criticism and recognise their different interests. 


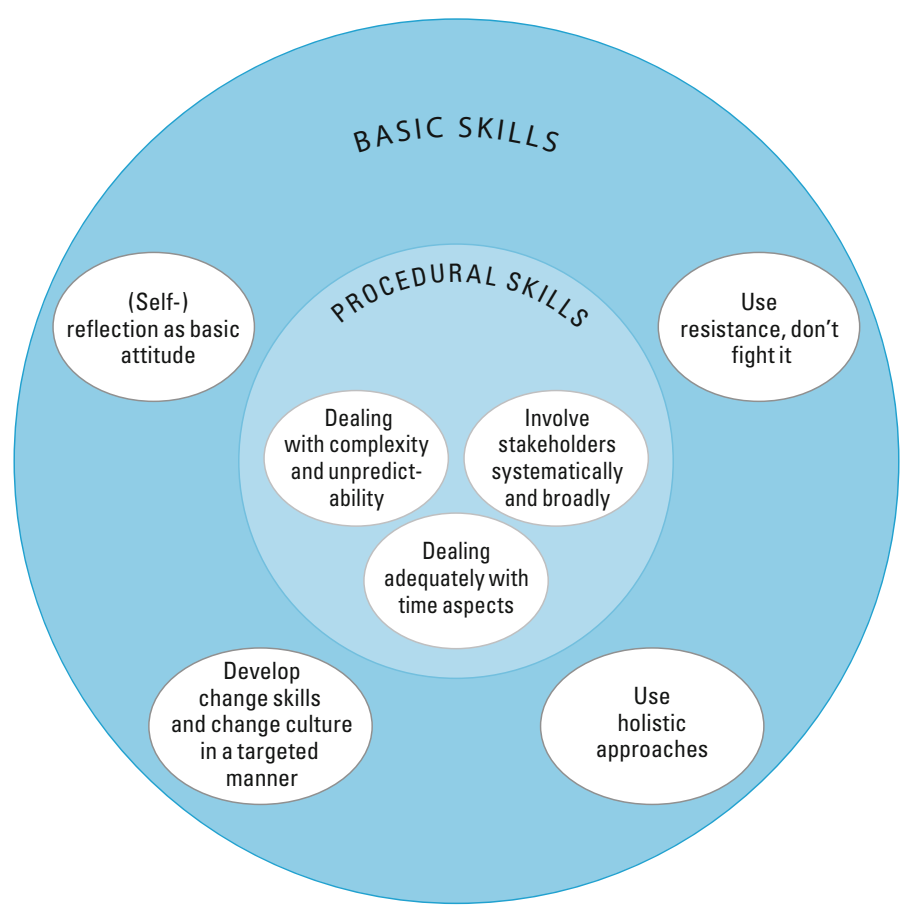

Fig. 17.1 Models of change: basic and procedural skills (copyright by the author)

Resistance is always a good indicator of the potential for improvement of the change idea, the proposed solutions or the change process. If you understand resistance, you can also use it in a solution-oriented way. Residual resistances can be weakened, for example, by compensating for disadvantages or sharing advantages.

Complexity is the norm in fundamental change. Actors must, therefore, abandon the idea that change can be controlled and learn to deal adequately with complex dynamic systems. An analysis of the system relevant to the change is the basis for being able to orient oneself. Starting from the basic vision and the core goals of the change agents, the aim is to identify both the central problems, risks, conflicting goals, dynamics and tipping points as well as the central levers and 'low hanging fruits'.

In addition to scientific expertise, system, process and experiential knowledge as well as competences in pattern recognition, creativity and intuition should be used in the analysis-because complex systems cannot be analysed completely, but a better understanding of the system can be achieved through different perspectives (Stark et al., 2017; Sommer \& Welzer, 2014). The development of these holistic competences should be specifically promoted in education and training.

At the same time, scenarios and models of possible future developments can help to better recognise the interrelationships and possible effects of action or non-action, to make directionally sound decisions for different possible future developments and to 
draw conclusions for today's actions. Scenarios show, for example, that some instruments would show good results in quite different developments and other instruments only fit well in a certain future development.

Since complexity can never be fully understood, problems with serious consequences can also arise unexpectedly. Therefore, it makes sense to always include the 'necessary safety margin'. In the environmental policy debate, the precautionary principle, reversible or correction-friendly solutions and resilience are, therefore, discussed for the selection of instruments and measures. But the process of change can also be adapted accordingly: iterative procedures to solve emerging problems in small steps, testing on a small scale and solution diversity to limit the problems to a manageable area, as well as monitoring to quickly identify the problems.

Time is relevant to the success of change in many ways. In change processes, different, often incompatible time logics usually collide (e. g. temporal routines, speeds, time horizons such as quarterly figures, election periods, biological cycles). Furthermore, the temporal scope plays a role - in terms of the consequences of action (e. g. short-lived pollutants, climate impacts, extinct species) as well as the measures and instruments taken (e.g. temporary driving bans to reduce emissions, restructuring of the energy system). Change processes also build on a history and have an impact on the future. Change agents need to be aware of the impact of the past on change processes in order to specifically reap the 'fruits' of the past and not fail because of old problems. Today's decisions also create the conditions for future change or prevent it (e.g., path dependencies, irreversible developments).

Since time logics and path dependencies have a great influence on change processes, they must be recognised and actively used in the change process (e.g., align change processes with election cycles and the windows of opportunity that open up in the process).

Change processes also need a lot of time. Since time is scarce, it is important to prioritise and focus consistently. This sounds trivial, but change processes often fail because the time required is significantly underestimated and insufficiently prioritised by the involved actors. Change agents underestimate the time they need to develop options with the target group, to resolve resistance and conflicting interests and to accompany participants in the change process when problems arise. Learning processes of the target groups to adapt to the change (e. g. changing behavioural routines, acquiring new qualifications) often take longer than expected.

Moreover, the temporal structures of changes in complex systems can only be described to a limited extent. Therefore, the timing of different activities can only be an approximation that needs to be continuously developed through monitoring. Deceleration can also be an important option.

Sometimes (unexpected) windows of opportunity open up and offer new opportunities for change (e.g., changed framework conditions, new actors, crises, new resources for change processes). In order to take advantage of these windows of opportunity, actors need to recognise them early and be prepared for them (e. g. create a knowledge base, develop attractive 'blueprints' in pilot projects), because they sometimes close again so quickly that there is not enough time to develop ideas and proposed solutions until then. 


\subsubsection{Central Process Elements}

In addition to the central change skills, promising patterns for change processes can be identified (see Fig. 17.2).

This involves inspiring visions and narratives, which are often the 'source of energy' for change processes. These should be combined with related core goals and viable initial proposals for solutions as well as the framework conditions for dissemination. In addition to establishing the new (phase-in), it is always a matter of replacing the existing (phase-out or exnovation).

Amongst the success patterns of change processes, small-scale testing is often insufficiently appreciated, because one would rather have 'large solutions immediately'. The typical complexity of fundamental changes, however, speaks in favour of testing on a small scale such as niche developments, pilot projects or real-life laboratories. This makes it possible to develop different solutions, learn from problems that arise, reduce risks and avoid resistance. In addition, the new and its advantages become concrete.

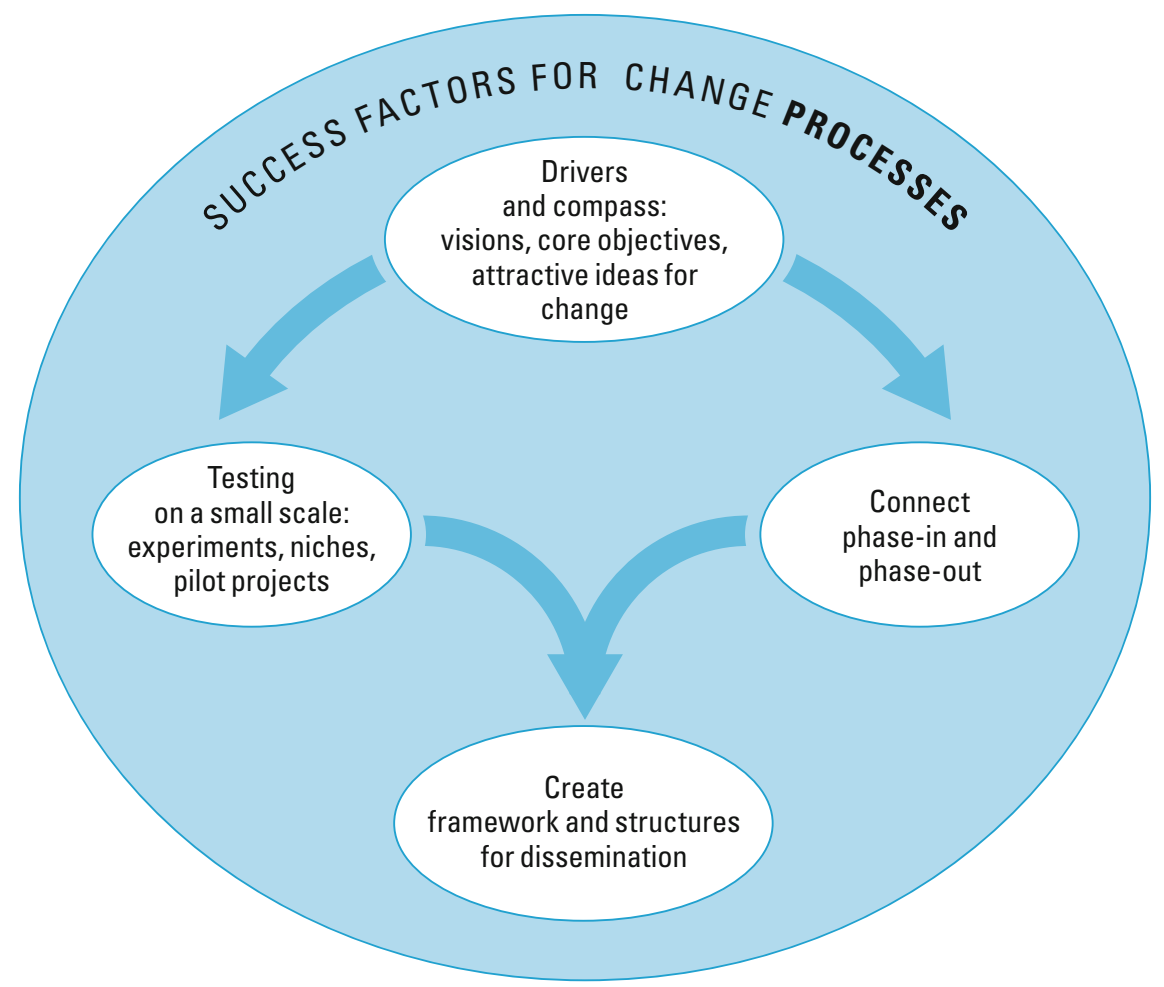

Fig. 17.2 Models of change: central process elements (copyright by the author) 
Disseminating the solutions becomes easier if the solutions are already developed on a small scale in such a way that they can be connected for dissemination (e.g. through modular and adaptable solutions, etc.). Dissemination can then also be secured in the longer term through government frameworks, new institutions, new business models or changing routines of those affected. In a dynamic world, however, the solutions can quickly prove to be no longer suitable.

In addition to establishing the new (phase-in), it is also always a question of replacing the existing (phase-out/exnovation). This also requires a change process of its own. The mostly different actors of phase-in and phase-out should network well in order to be able to tap synergies. An important part of the exnovation process is that the change actors deal with what is to be replaced in a differentiated way. In doing so, the deficits of the existing as well as its losers and beneficiaries should become transparent. It must also be questioned whether the existing can always remain the 'normal case' in a changing world.

\subsubsection{Entire Process and Consistently using Success Factors}

Figure 17.3 combines the central skills and successful patterns with a look at the entire process of the change.

The analysis creates orientation and is the basis for the visions, the core objectives and the first ideas for implementation. Agenda setting makes it possible to set up a change process, to involve stakeholders and to reach an agreement on the process. Solutions are sought together with all stakeholders and developed step by step. It is also important to think about the concrete implementation of the new and its dissemination as well as the replacement of the old. Since there can be no optimal and permanently valid solutions in a complex and dynamic world, the process of change is never completed.

In a complex world, this process of change does not proceed step by step one after the other and the different activities are not independent of each other.

It is very challenging to think in terms of overall processes and to continuously keep an eye on all central success factors. The core skills as well as the successful patterns of change processes should be used consistently throughout the entire change process.

\subsection{Conclusion: Using Success Factors and Building Up Skills}

It is clear that in a complex world, changes cannot be planned in detail. But what can be identified are important success factors and patterns of successful change. So, two tasks arise 


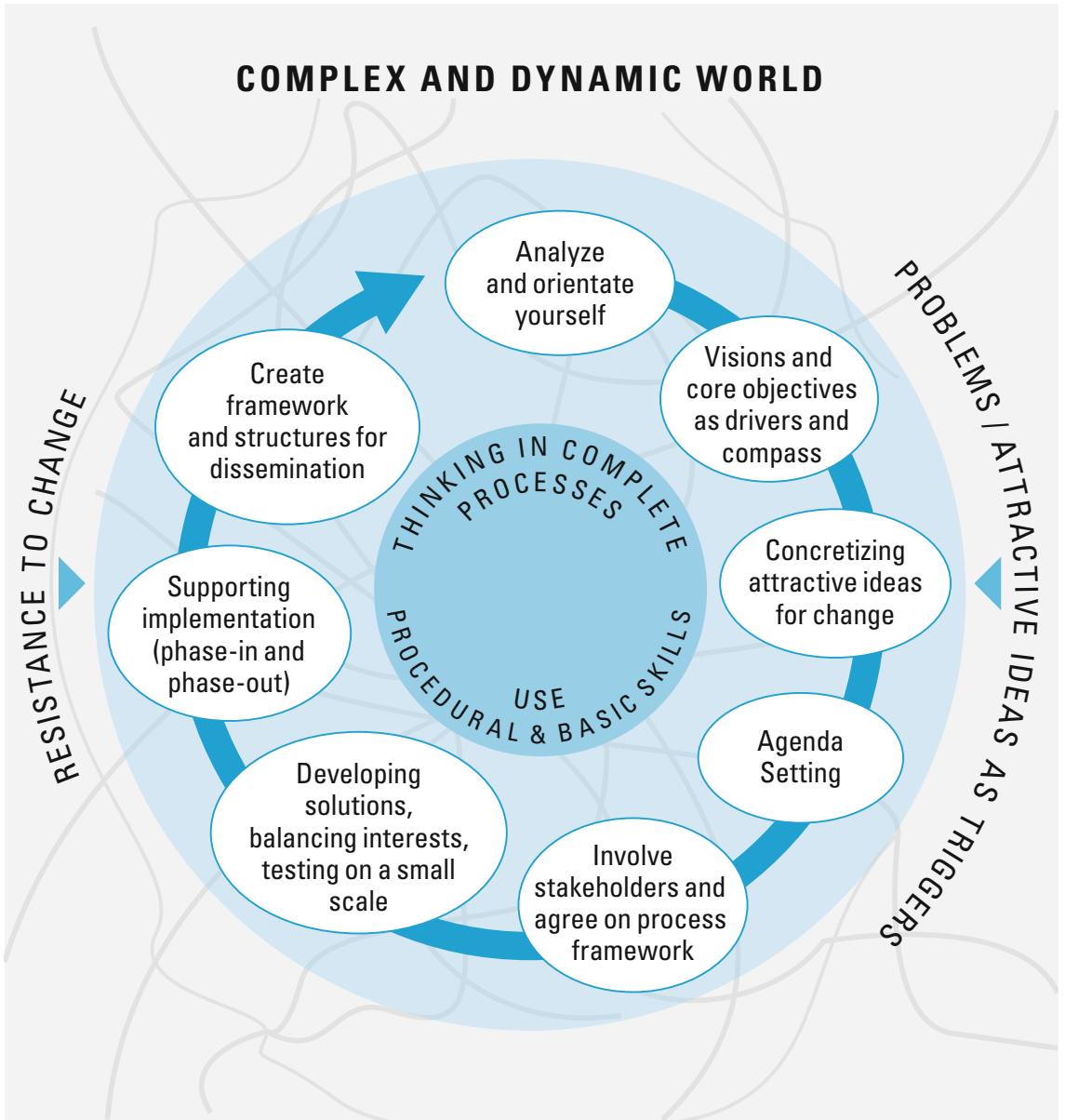

Fig. 17.3 Models of change: entire process and consistently using success factors (copyright by the author)

On the one hand, to look ex-post at what has worked or not and why,

on the other hand, to identify ex-ante success factors and success patterns and to use them consistently.

Success in change processes requires that the change agents have the central change skills and know the central success factors and patterns.

For changes towards sustainability, people often rely on the implicit models in their own heads. In other areas of our lives, we are more professional: we take sports courses or go to music lessons.

We should also become more professional in change processes, making targeted use of the knowledge gained and building up the necessary skills - in schools, universities and in professional training. 
The first teaching programmes on the success factors from transformation research have already been developed (for example in our project 'Transformation wagen ('Dare to transform'; www.polsoz.fu-berlin.de/en/polwiss/forschung/systeme/ffu/ forschung-alt/projekte/laufende/19_TrafoWag/index.html or by Smart CSO). This kind of training opportunities should be actively used.

\section{References}

Alexander, C., Ishikawa, S., \& Silverstein, M. (2011). Eine Muster-Sprache: Städte - Gebäude Konstruktionen, 2nd ed. Löcker.

Daschkeit, A., Kristof, K., Lorenz, U., \& Veenhoff, S. (2013). Deutschland bis zum Jahr 2050 Bausteine für eine nachhaltige Zukunft. Jahrbuch Ökologie 2014.

Ernst, A., \& Welzer, H. et al. (2015). Scenarios of perception of reaction to adaptation, final report of the 'SPREAD'-project.

Fünfschilling, L. (2014). A dynamic model of socio-technical change: Institutions, actors and technologies in interaction.

Geels, F. W. (2011). The multi-level perspective on sustainability transitions: Responses to seven criticisms. Environmental Innovation and Societal Transitions, 1(2011), 24-40.

Grießhammer, R. et al. (Öko-Institut / Kulturwissenschaftliches Institut / Zeppelin Universität) (2015). Wie Transformationen und gesellschaftliche Innovationen gelingen können.

Heinecke, H. J., Kristof, K., Pfriem, R., Smrekar, O., \& Stark, W. (2013). Veränderungsfähigkeit lernen: Initiative für eine Schule zur Kunst des Wandels. GAIA, 22 (1), 34-38.

Jackson, T. (2009). Prosperity without growth? The transition to a sustainable economy.

Köhler, J., et al. (2019). An agenda for sustainability transition research: State of the art and future directions. Environmental Innovation and Sociretal Transition, 31(2019), 1-32.

Kristof, K. (2010a). Models of Change: Einführung und Verbreitung sozialer Innovationen und gesellschaftlicher Veränderungen in transdisziplinärer Perspektive. vdf Hochschulverlag an der ETH Zürich.

Kristof, K. (2010b). Wege zum Wandel: Wie wir gesellschaftliche Veränderungen erfolgreicher gestalten können. oekom.

Kristof, K. (2020). Wie Transformation gelingt: Erfolgsfaktoren für den gesellschaftlichen Wandel. oekom.

Loske, R. (2012). Wie weiter mit der Wachstumsfrage? Basilisken-Presse.

Oberlack, C. (2019). Theories of change in sustainability science: Understanding how change happens. GAIA, 28 (2), 106-111.

Rasmussen, C. (2013). Green Transformation: grüne Managementkompetenz für zukunftsfähige Unternehmen. Leitfaden 01 bis 04.

Rockström, J., et al. (2009). A safe operating space for humanity. Nature, 461, 472-475.

Rotmans, J., \& Loorbach, D. (2009). Complexity and transition management. Journal of Industrial Ecology, 13(2), 184-196.

Rückert-John, J., Jaeger-Erben, M., \& Schäfer, M. (2014). Soziale Innovation im Aufwind: Ein Leitfaden zur Förderung sozialer Innovationen für nachhaltigen Konsum.

Schäpke, N., et al. (2018). Jointly Experimenting for Transformation? Shaping Real-World Laboratories by Comparing Them. GAIA, 27(S1), 85-96.

Schneidewind, U. (2018). Die Große Transformation: Eine Einführung in die Kunst gesellschaftlichen Wandels. Fischer.

Schneidewind, U., \& Singer Brodowski, M. (2013). Transformative Wissenschaft: Klimawandel im deutschen Wirtschafts- und Hochschulsystem Metropolis

Smart CSO. (2011). Effective change strategies for the Great Transition: Five leverage points for civil society organisations. 
Smart CSO (Narberhaus, M., \& Sheppard, A.) (2015). Re.imagining activism: A practical guide for the Great Transition.

Sommer, B., \& Welzer, H. (2014). Transformationsdesign: Wege in eine zukunftsfähige Moderne. München: oekom.

Stark, W., Vossebrecher, D., Dell, C., \& Schmidhuber, H., (Hg.) (2017). Improvisation und Organisation: Muster zur Innovation sozialer Systeme. Bielefeld: transcript.

Wagner, F., \& Grunwald, A. (2019). Real-world labs: popular, arbitrary, or something in between: Taking stock of this transformative design. GAIA ,28 (3), 260-264.

WBGU. (2011). Gesellschaftsvertrag für eine Große Transformation.

Welzer, H., \& Sommer, B., et al. (2014). Wie gute Beispiele nachhaltigen Handelns in einem breiten gesellschaftlichen Kontext verankert werden können. Final report/UFOPLAN-project 'Von der Nische in den Mainstream /FKZ 371311102.

Wolff, F., \& Jacob, K., et al. (2018). Transformative Umweltpolitik: Nachhaltige Entwicklung konsequent fördern und gestalten.

Open Access This chapter is licensed under the terms of the Creative Commons Attribution 4.0 International License (http://creativecommons.org/licenses/by/4.0/), which permits use, sharing, adaptation, distribution and reproduction in any medium or format, as long as you give appropriate credit to the original author(s) and the source, provide a link to the Creative Commons license and indicate if changes were made.

The images or other third party material in this chapter are included in the chapter's Creative Commons license, unless indicated otherwise in a credit line to the material. If material is not included in the chapter's Creative Commons license and your intended use is not permitted by statutory regulation or exceeds the permitted use, you will need to obtain permission directly from the copyright holder. 